\title{
(Digital) neo-colonialism in the smart city
}

\section{Morgan Mouton \& Ryan Burns}

To cite this article: Morgan Mouton \& Ryan Burns (2021) (Digital) neo-colonialism in the smart city, Regional Studies, 55:12, 1890-1901, DOI: 10.1080/00343404.2021.1915974

To link to this article: https://doi.org/10.1080/00343404.2021.1915974

$$
\text { 曲 Published online: } 17 \text { May } 2021 .
$$

Submit your article to this journal $₫$

\section{Lll Article views: 860}

Q View related articles $\square$

View Crossmark data \lceil

4 Citing articles: 5 View citing articles 진 


\title{
(Digital) neo-colonialism in the smart city
}

\author{
Morgan Mouton ${ }^{\mathbf{a}} \odot$ and Ryan Burns ${ }^{\mathbf{b}} \odot$
}

\begin{abstract}
The critical research agenda on smart cities has become increasingly interested in the political-economic relations between digital technologies and everyday urban life. It is now clear that in the smart city, quotidian activities have become valorized as data, and are produced, extracted and circulated with little, if any, remuneration to those individuals from whom they have been abstracted. Smart-city scholars often call this process 'digital colonialism' to highlight the uneven relations of power that enable processes of dispossession and profit generation. In this article we argue that greater conceptual clarity is needed around digital colonialism. Specifically, what is called 'digital colonialism' often entails processes more characteristic of neo-colonialism. By teasing out the differences between digital colonialism and digital neo-colonialism, different relations and processes are illuminated, allowing us to theorize the smart city with greater nuance. Here, we focus on the epistemological claims, practices of legibility and repercussions that emerge when focusing attention on the latter. We show that digital neo-colonialism also requires different political strategies of resistance than its colonial counterpart, and we grapple with the multiple ways in which digital technology research has formulated resistance strategies. We advocate for a collective, structural shift in how data and digital technologies are deployed and circulated within the smart city. To substantiate these claims, we draw on a long-term, ongoing database ethnography in Calgary, Alberta, Canada.
\end{abstract}

\section{KEYWORDS}

smart cities; digital neo-colonialism; digital geographies; digital political economy

JEL O30, P16, R11, Z1

HISTORY Received 9 November 2019; in revised form 16 March 2021

\section{INTRODUCTION}

You grant FaceApp a perpetual, irrevocable, nonexclusive, royalty-free, worldwide, fully-paid, transferable sub-licensable license to use, reproduce, modify, adapt, publish, translate, create derivative works from, distribute, publicly perform and display your User Content and any name, username or likeness provided in connection with your User Content in all media formats and channels now known or later developed, without compensation to you.

(FaceApp Terms and Conditions)

At the time of writing, the FaceApp application ${ }^{1}$ is as popular as electric scooter rentals, bikeshare programmes, public wi-fi hotspots, and Instagram or Snapchat filters. This is urban living in 2019. As FaceApp reached viral status in the early summer, many began raising concerns about the way in which the terms of service extract and secure a shocking level of information and value from its users. Indeed, by reasonable standards of the lay user, they are egregiously invasive. However, while this app concentrated a significant amount of the public's ire, its level of extraction is present in most apps on which the 'smart city' relies. One might even submit that this level of concern should have been long entrenched against more common apps and platforms with more clandestine data-collection methods - FaceApp, in fact, might be the least of our concerns in the smart city.

Defining the smart city has been a persistent research challenge, but here we take the one offered by Kitchin et al. (2015b, p. 18): 'the roll-out of new information and communication technologies (ICTs) and neoliberal visions of market-led and technocratic solutions to city governance and development, [which] are promoted as pragmatic, non-ideological and commonsensical in approach', and we underscore the increasing regionalization of such programmes (Calzada, 2017). Within the ever-growing smart cities literature on the social and

\section{CONTACT}

${ }^{a} \otimes$ Morgan.mouton@u-pem.fr

Lab'Urba, Université Gustave Eiffel, UPEC, EIVP, Champs-sur-Marne, France; and O'Brien Institute for Public Health, University of Calgary, Calgary, AB, Canada.

${ }^{\mathbf{b}}$ (Corresponding author) Ryan.burns1@ucalgary.ca

Department of Geography, University of Calgary, Calgary, AB, Canada; and Department of Geography, University of California Berkley, Berkley, CA, USA. 
political implications of increasingly digitized urban spaces, we are particularly concerned with how data are emerging as a new 'resource' that drives new forms of urban capitalism. The profusion of data is indeed a major condition for the existence of smart city-regions (Kitchin, 2014b; Townsend, 2013), and Sadowski (2019, p. 1) argues, in fact, that 'data - and the accumulation of data - is a core component of political economy in the 21st century', establishing a parallel between data and capital in contemporary capitalism. If the production of data and its subsequent accumulation is propelling urban capitalism to a new stage, what are its implications for urban living? In line with authors who have highlighted the performative nature of narratives around 'smartness' (Picon, 2013; Söderström et al., 2014), we situate this debate on epistemological grounds. As smart city-region discourses offer depoliticized and oppressive visions of the world, we seek to repoliticize their framing, and call for the reappropriation of their imaginaries (Hollands, 2015; Sadowski \& Bendor, 2019).

More specifically, this effort towards repoliticization involves giving more thoughts to the relationship between 'data' and 'smart cities'. There is now a well-established critique of the 'datafication' of cities from the standpoint of surveillance practices, with authors conjuring Deleuze's (1990) notion of 'societies of control' and warning against new, pervasive exertions of disciplinary power (Sadowski \& Pasquale, 2015; Vanolo, 2014). However, the processes of data accumulation still merit further documentation and conceptualization. Within emerging debates in digital geographies, many concepts and terms remain unclear. The value chain for data would for some be called 'digital colonialism' (Thatcher et al., 2016) or 'data colonialism' (Couldry \& Mejias, 2019a). At a very rudimentary conceptual level, data colonialism might imply an analytical focus on the abstraction of life into bits and bytes. Digital colonialism might presumably encapsulate those data but also extend the scope of analysis to other dimensions of the digital - we could reflect, for instance, on the hardware and infrastructure that subtend our use of the Internet. Hence, we understand data colonialism as a subset of digital colonialism. However, even the term 'digital colonialism' itself in much of the literature seems to lack conceptual clarity and perhaps even miss important connections with the actually existing histories and geographies of a non-metaphorical 'analog' colonialism. When scholars use the term 'digital colonialism', to us it often reads far more like Young's (2016) theorization of neocolonialism, with strong connections to imperial forms of political, cultural and economic domination. We contend that digital colonialism, then, is often used as a synonym for digital imperialism and, more pertinently for the current article, neo-colonialism.

In this article, we demonstrate how the smart cityregion mobilizes a distinctly neo-colonial collection of social and political relations. To get there, we encounter the need to conceptualize more fully what is particularly 'neo' about the relations, contra the existing literature that tends to focus on colonialism proper. Along the way, we situate digital colonialism and digital neo-colonialism alongside what might be thought of as a digital (highest?) stage of imperialism, to paraphrase Lenin (1999). In short, our goal is to advance theorizations of the smart city, and in doing so we secondarily further the conceptualization of digital (neo-)colonialism. We see these goals as commensurable and mutually necessary. To be sure, the guiding contention here is not around terminology per se, but about the purchase of different conceptual apparatuses that scholars might leverage to understand the confluence of digital and urban processes. By operating a distinction between digital colonialism and neo-colonialism, our objectives are threefold. Aggregating a wide variety of phenomena under the single umbrella of 'digital colonialism' can weaken its conceptual value: our first objective is therefore to clarify the terms of the debate. Second, we argue that the distinction we propose sheds light on processes of domination that would otherwise remain blurred. Third, we argue that this distinction raises important considerations for the political tactics mobilized to resist digital neo-colonialism. In other words, by clarifying our conceptual terms, we may more deeply understand the processes and relations that they seek to explain, and modify political strategies accordingly. One may look to Datta's (2018) exposition of postcolonial smart cities and emergent forms of what she terms the 'chatur citizen' to see the stakes of conceptual clarity around such terms.

The rest of this paper is organized according to these goals. Next, we demonstrate the heuristic value of our conceptual distinction by reflecting on smart city initiatives rolled out by the City of Calgary in Alberta, Canada. We ascertain that because of the actors involved at the municipal level, processes of neo-colonialism are dominant in this case study. In this case, the city government serves as little more than a facilitator of neo-colonial relations. More specifically, we highlight the value of a digital neo-colonial conceptual lens and framework for unpacking the mechanisms of legibilization and inclusion/exclusion at work in the digitally enhanced urban fabric. We then open new lines of enquiry for resisting this particular form of digital neo-colonialism, calling for more dialogue between activists and digitally minded scholars.

\section{WHAT IS DIGITAL NEO-COLONIALISM?}

Scholarship in urban studies has put smart city-regions in the spotlight (Hollands, 2008; Marvin et al., 2015; Picon, 2015), and emphasized how digital technologies such as sensors, dashboards and data are seen to potentially solve (or, at least, address) persistent urban problems (Kitchin, 2014a; Krivý, 2018; Murakami-Wood \& Mackinnon, 2019; Picon, 2018). Within this literature, it is increasingly recognized that 'smart' policies are deployed across scales of government beyond municipal boundaries, often reinforcing the influence of cities vis-à-vis the regions they sit in (Calzada, 2017). Much research in this area has begun theorizing complex political-economic relations, 
such as the degree to which smart city-regions align with neoliberal reforms and imperatives (Odendaal, 2016). Against this backdrop, we review the need for new conceptual tools that can help us build an understanding of smart city-regions.

\section{Digital colonial origins}

As the 'datafication' of our daily lives (Cheney-Lippold, 2018; Neff \& Nafus, 2016; Ruckenstein \& Schüll, 2017) progresses and attracts mounting attention in academic realms, scholars find themselves in need of new conceptual tools to make sense of the latest developments in dataintensive forms of capitalism.

In recent years, the concepts of 'digital colonialism' and 'data colonialism' have gained considerable currency (Couldry \& Mejias, 2019a, 2019b; Kwet, 2019; Mann \& Daly, 2019; Sting1, 2015; Thatcher et al., 2016; Young, 2019), opening new and exciting lines of enquiry into the processes of extraction, processing, aggregation, commodification and/or exploitation of our digital selves. We recognize that emerging scholarship has not yet stabilized, and that concurrent conceptions of digital colonialism coexist. More specifically, we identify two strands of the literature that offer different conceptualizations of digital colonization. A first one compares the 'digital realm' with a new continent, a new frontier waiting to be explored and exploited, while tech companies could be viewed as modern caravels - for the sake of clarification we can call it the 'metaphorical' conceptualization. As Couldry and Mejias (2019a, p. 337) put it, 'Data colonialism combines the predatory extractive practices of historical colonialism with the abstract quantification methods of computing.' In other words, as our daily lives and our very bodies increasingly become intertwined with the digital, they become subject to practices of commodification. In this, they draw to a small extent - but explicitly - on Habermas's (1989) notion of the colonization of the lifeworld, which they admit 'is not developed as a theory of colonialism' (Couldry \& Mejias, 2019a, p. 227). ${ }^{2}$ Of note, authors in this field have identified several limits to this metaphorical conceptualization: most importantly, data are not a resource that is just awaiting discovery, but rather an asset that needs to be constructed (Sadowski, 2019). Along these lines, Thatcher et al. (2016, p. 994) mobilize Harvey's (2014) concept of 'accumulation by dispossession' to describe how data are produced, and then 'extracted from the producers to capture surplus value'.

A second conceptualization of digital colonization rather emphasizes that the use of digital technology extends, and reinforces, existing forms of colonialism. For instance, Young (2019) uses this concept to study how the introduction of ICTs within Indigenous communities of the Canadian Arctic. Meanwhile, Kwet (2019) analyses how multinational technology companies take part in resource extraction in South Africa, through rent and surveillance. Here Kwet makes a parallel between the building of roads and railways by colonial powers, and the rolling out of (proprietary) hardware and software by Western companies that leaves South African citizens disempowered, and South African companies unable to compete with American firms. While we acknowledge the value of this polysemy, we argue it strengthens our call for a clarification of the terms of the debate.

\section{Enter: digital neo-colonialism}

Just as the difference between colonialism and neo-colonialism is, in part, diachronic, our distinction between digital colonialism and digital neo-colonialism is concerned with chronology. The notion of neo-colonialism was coined in the 1960s (Nkrumah, 1966; Sartre, 2005), and emerged out of a need to describe new forms of domination exerted by Western powers over their formers colonies, despite the formal independence of the latter. Nkrumah (1966) in fact argues that:

The essence of neo-colonialism is that the state which is subject to it is, in theory, independent and has all the outward trappings of international sovereignty. In reality its economic system and thus its political policy is directed from outside.

(p. ix)

As a consequence, neo-colonialism helps document and analyse phenomena of domination that are more indirect, more diffuse, and perhaps subtler than outright coercion. It also leads to the realization that $\mathrm{Neo}$-colonialism is the worst form of imperialism. For those who practice it, it means power without responsibility and for those who suffer from it, it means exploitation without redress' (p. xi).

That being said, and just like colonialism and neocolonialism have coexisted and still continue to coexist (Jason C. Young, personal communication), we do not mean to argue that the era of digital colonialism is over. It still is very much present, as we will argue in the following subsection - but it is no longer the only phenomenon of digital imperialism that we need to consider.

What are the mechanisms of domination that we want to highlight in the digital age, and how do they relate to the (neo-)colonialism metaphor? To work toward a provisional answer, we propose focusing on characteristics that include (1) the kind of actors involved, (2) the mechanisms they mobilize and (3) the discourses they produce to legitimize their actions - as presented in Table 1. Overall, we question the ways that scalar relations are produced and invoked in order to enact relations of power and accumulation (a similar approach to the one taken by Sadowski \& Pasquale, 2015). Such questions are meant to lead into a critical analysis of such processes, and are not meant to be definitive in scope; in other words, they are meant to provoke further questions to deepen insights into the mechanisms of domination. As we explain each of these below, it becomes clear that the different socio-political arrangement necessitates a shift in political tactics collectives mobilize to resist these new forms of oppression and extraction.

- First, we contend that it is helpful to consider the kinds of actors involved. Colonial histories are heterogenous 
Table 1. The distinctions and relations between multiple forms of colonialism.

\begin{tabular}{|c|c|}
\hline Analogue & Digital \\
\hline \multicolumn{2}{|l|}{ Colonialism } \\
\hline Single-state control & Strong, direct-state control (e.g., ICANN before 2016) \\
\hline Direct control & $\begin{array}{l}\text { Package routing (PRISM of the National Security Administration } \\
\text { (NSA)) and server sovereignty (e.g., China and server } \\
\text { requirements for Baidu) }\end{array}$ \\
\hline Occupation and infrastructure development & Building/establishing the digital \\
\hline Claim to local benefit: civilization & Claim to local benefit: state capacity for development, security? \\
\hline Common resistance: military and diplomatic & $\begin{array}{l}\text { Common resistance: technological (e.g., local data storage, } \\
\text { VPNs, Tor) }\end{array}$ \\
\hline \multicolumn{2}{|l|}{ Neo-colonialism } \\
\hline Shifting state masters & Multiple platforms exerting diffuse control \\
\hline Indirect control through economy and culture & $\begin{array}{l}\text { Normalized epistemology embedded in digital tools (with } \\
\text { consequences for legibility and inclusion in the smart city- } \\
\text { region) }\end{array}$ \\
\hline States are 'sovereign' & Individuals are 'sovereign' \\
\hline Claim to local benefit: development & Claim to local benefit: inclusion and service delivery efficiency \\
\hline $\begin{array}{l}\text { Common resistance: economic and diplomatic (e.g., } \\
\text { disengagement from treaties on tariffs and trade, creation of } \\
\text { new international coalitions) }\end{array}$ & $\begin{array}{l}\text { Common resistance: individual practices (e.g., browser plug-ins, } \\
\text { wearable garments); requisite resistance: collective (e.g., } \\
\text { protests, outlawing facial recognition), structural (e.g., Creative } \\
\text { Commons licences, open-source software) and anti-capitalist } \\
\text { (e.g., breaking up big companies) }\end{array}$ \\
\hline
\end{tabular}

Note: ICANN, Internet Corporation for Assigned Names and Numbers; and VPNs, virtual private networks.

(Young, 2016), and colonial powers have been entangled with private actors (Flint \& Taylor, 2018) the British and Dutch East India companies being prominent examples. However, a notable difference between colonization and neo-colonization is the role of nation-states, which remains in the background in contemporary forms of neo-colonial domination. Along the same lines, we propose highlighting the dominance of platforms in contemporary forms of data extraction and accumulation.

- Consequently, the form of control exercised by platforms is pervasive in nature - as opposed to direct surveillance (e.g., requiring Internet Protocol (IP) addresses to be matched with individuals' administrative data). To carry the metaphor further, we could say that the initial step of digital colonialism hinged upon a digital actualization of the Regalian doctrine (jura regalia) - a founding principle of Spanish colonial law establishing that 'private title to land must emanate, directly or indirectly, from the Spanish crown with the latter retaining the underlying title' (MacKay, 2004, n.p.). As digital infrastructure was being instituted, nation-states legitimized their interventions in, and regulation of, the digital realm on a similar basis of underlying ownership. Contemporary manifestations of this digital jura regalia can be found in calls for state sovereignty with regards to data storage, with examples ranging from the European Union's General Data Protection Regulation (GDPR) to the law requiring Chinese customer data and cloud computing to be stored on China-based servers (KPMG, 2017). But such principles have become concurrent with forms of neo-colonial control - even in contexts that we associate with strong state control. Liang et al. (2018) show, for instance, how the Chinese 'social credit system' involves a complex network of actors that span far beyond public administration, and entails forms of control that primarily involve financial and commercial activities rather than the direct surveillance of individuals' social and political activities. In the next section we will document how mechanisms of domination can be embedded in software code and administrative categories that impose dominant epistemologies, affect urban governments' legibility over urban life and, ultimately, dictates who belongs (or not) in the smart city-region.

- Finally, in contrast to digital colonialism, this new(er) form of imperialism presents itself as a service that individuals can 'opt-out' of, thus echoing neoliberal conceptualizations of individuals as subjects of human capital (Brown, 2015; Foucault, 2004). Unlike state-led forms of control that are imposed over the entire population of a given territory, smart citizens are framed as 'sovereign' entities that can choose whether they want to use a particular service, and shift to another service provider should they wish to (to be sure: in drawing the parallels to neo-colonialism, we intentionally undermine this framing). Platforms' rationale for imposing terms and conditions similar to those opening this paper is that they provide 'convenient' and 'efficient' services. 
The tribulations of the Internet Corporation for Assigned Names and Numbers (ICANN) offer a powerful illustration of the processes we are describing. In the late 1990s, the US government made a move toward more direct control over two critical resources for the Internet: IP addressing systems and Domain Name System (DNS). Their management would now be run by a private organization, from US territory and 'and without substantial participation of governments - except [the US government]' (Oppermann, 2018, p. 33). As ICANN pursued its mission, it became evident that countries of the Global South were being marginalized in the digital realm - the participation of their companies in the ICANN registrar business was low, and sometimes even declining over time (p. 34). DNS and IP numbers have to do with online identity, and dictate what can be found, or not, on the Internet (White, 2018): their management has repercussions at the global scale that extend far beyond mere 'technicity' and impact economic, social, political and cultural life. It is unsurprising, then, that Southern countries eventually contested this US control over ICANN. This control formally ended in 2016 as the contract binding ICANN to the US government was allowed to expire, thus unveiling the organization's 'multi-stakeholder model' in which actors from the public sector, the private sector and technical experts work towards a 'communitybased consensus-driven approach to policy-making' (ICANN, n.d.). This new form of governance strongly relies on free-market principles, and has been strongly criticized for corporate capture, which translates, for instance, in the unfair allocation of IP addresses (White, 2018). In other words, the US government relinquished direct control over ICANN, but the organization has engaged in a decision-making process that marginalizes countries of the Global South as well as non-commercial groups internationally. We can make sense of ICANN's evolution by thinking of it as a shift from digital colonial imperatives - that is, direct state control and extraction of value - to digital neo-colonialism - the state as a facilitator of private accumulative practices.

We argue that in smart city/regions, state actors are not necessarily dominant: many phenomena unfolding in the (smart) urban fabric are better captured through the mobilization of a neo-colonial analytical lens. They involve a plethora of public and private actors, and operate data capture not through direct coercion, but rather through the inconspicuous diffusion of standards and norms. Where does this proposition leave us with regards to the everyday experience of urbanites in smart city-regions of the Global North? Can data-extraction practices occurring within city-regions of the Global North be framed as forms of digital colonialism? Drawing upon well-established traditions (Flint \& Taylor, 2018; Wallerstein, 2004), we wish to focus on oppression occurring both between nation-states and within them, and we therefore argue that digital colonialism can indeed be mobilized in the North. We need to pay attention to power relations between countries and to analyse how data are yet another instrument in the exertion of domination from the Global
North, yet we also acknowledge the variety of interests within countries, and highlight aggressive forms of data extraction that target marginalized populations inside a given country. Taken together, the new (neo)colonial relations necessitate re-evaluating the practices we mobilize to resist these new forms of oppression and extraction. Against this backdrop, the next section will elaborate on digital neo-colonialism using the example of Calgary.

\section{THE DIGITAL NEO-COLONIAL SMART CITY}

Here we draw on an ongoing research project in Calgary, Alberta, Canada, to interrogate the ways in which a digital neo-colonial smart city has emerged over the last decade. More precisely, we contend that turning a particularly neo-colonial conceptual lens on the processes and relations of the Calgarian smart city can help elucidate its attendant political economies and social relations. To be sure, elements of the Calgarian smart city might still be properly called 'digital colonial', but here we want to tease out aspects that, if we conceive of them as digital neo-colonial, draw to our attention different actors, relations and processes. We consider here, in turn, the epistemological claims and priorities of Calgary's smart city, the ways in which these epistemologies become legible and make particular knowledges and processes legible, and finally what all this means for the politics of inclusion and exclusion in the smart city. Throughout, we intentionally tease out the inherent contradictions of these emergent neo-colonial approaches and paradigms, pointing to their cracks, ruptures and spaces for contestation.

The research on which we draw is a multi-year (201620) qualitative study that combines elements of the extended case method (Burawoy, 1998) and the database ethnography (Burns \& Wark, 2019). The extended case method is a framework for recursively and reflexively generating theoretical propositions from evidence, similar to ethnography. The database ethnography 'dwells' in the database and in the socio-political contexts in which the database is developed, to see how this digital infrastructure produces and encapsulates social meaning. Practically, the data we collected that are pertinent for this article are comprised of over 40 semi-structured interviews, dozens of participant-observation activities at city events and local data and smart advocacy meetings, official city documents related to its smart city programme, news articles, and related materials. To generate insights from our data, we utilize discourse analysis (Dittmer, 2010; Jørgensen \& Phillips, 2002). Here we are interested in elucidating the means by which data achieves its social utility as an accumulation apparatus; our approach treats this process as discursive in nature, meaning that to extract data and accumulate its value requires the production of knowledge and articulations that enable and legitimate it.

\section{Epistemological claims and priorities}

'Smartness' has infused the City of Calgary's communication in recent years, as this Albertan city enthusiastically 
took part in Canada's Smart Cities Challenge (Burns \& Wark, 2019; Johnson et al., 2020) or advertised its smart citizen engagement (Levenda et al., 2020). The former was a $2015-17$ national mirroring of the United States' similarly titled programme, which awarded large prizes to cities who had offered compelling smart city proposals. As such, the municipal administration aligns its smart city epistemological framing closely to most other smart cities in extant literature, in that it primarily relies on a philosophically realist knowledge production framework that is strongly Euclidean in its purview. By 'realist' we simply refer to the understanding that there exists a world outside of the observer that is knowable through empirical observations (Bhaskar, 2008). This understanding has two key elements for us: first, it separates the observer from the observed object in a Cartesian duality; and second, it prioritizes knowledge generated through first-hand measurements. This contrasts with many other ways of knowing the world that, for instance, might see the 'world' and the observer as mutually constitutive via constructed knowledge systems, or others that understand knowledge as contingent and politically mediated. This realist approach to epistemology builds productively on a Euclidean view of phenomena, wherein occurrences take place at particular geometrical locations such as latitude-longitude coordinate pairs, or 'two kilometers away'. Such a charting out of space marginalizes the many relational, topological, and immaterial ways in which people interact with urban space, such as through feelings of belonging or danger, connectivity to services or resources and the social capital required to leverage them, and digital communities (Davis, 1998; Richardson, 2018). This realist and Euclidean epistemological framework is widely seen to be the case in smart city-regions, especially those in which big data is a core component (Kitchin et al., 2015a). Most importantly, below we show that these epistemological framings set up the smart city as a particularly digital neo-colonial terrain for private capital accumulation.

For Calgary, these epistemological priorities manifest largely in the city's open data platform Open Calgary. As Jean, a leader of the smart city programme, underscored the importance of Open Calgary to the city's vision of smartness: 'You can't have smart cities without open data.' By this, she meant that the key objectives and goals of Calgary's smart city programme are measurable, achievable and demonstrable through systems of data and databases that are partially - and in many ways, nominally - open to the public. As the city retains a large proportion of its operational, archival, and original datasets behind a paywall or on private, internal servers, the term 'open data' has always been a contingent and politically volatile term. Open Calgary's administration team, currently headed by our interviewee Graham, is well aware of its exclusions:

[Putting third-party data on Open Calgary] may not be something that we can actually do, because it's not our information to share.... I think that some of the data that could be more useful in the kind of Smart Cities broader open data realm, there might have to be some more interesting conversations that have to happen to make those available. ... [W] do not have crowdsourced information on the open data catalogue. To my knowledge there's also nothing that would stop a crowdsourced dataset from appearing there.

Juxtaposing Open Calgary data holdings with information from the city's policy documents illustrates how realism and Euclidean geometries collude in smart-city agenda. Open Calgary's offerings are limited almost entirely to quantifiable, mappable and standardizable phenomena (Figure 1), such as, to take a limited number of examples, traffic camera locations, election results and pedestrian collision injuries. Perhaps more aligned with common conceptions of 'smart technologies', Open Calgary also offers real-time bike and scooter share locations, bike and pedestrian counts detected from automatic sensors, and aggregated quality-of-life surveys that solicited yes/ no answers to questions about daily behaviours. Throughout, qualitative information has often been gathered using means that force it into a schema aligned with the overarching epistemological framework: satisfaction surveys, for example, use Likert scales and 'agree or disagree' binary questions. At the same time, these sorts of epistemological framings seep heavily into the city's policy documents that frame its smart city programmes. Figure 2 shows a slide from a city-hosted event in which Jean claimed that 'Calgary is already a smart city', positioning various dimensions into a hierarchy of smart city components. At each step in this hierarchy, Jean framed smart city problems and, importantly, their solutions, as quantitative in nature: infrastructure connectivity is knowable as coverage rates, and end-point devices are numbers of technical units that analyse and interact with data.

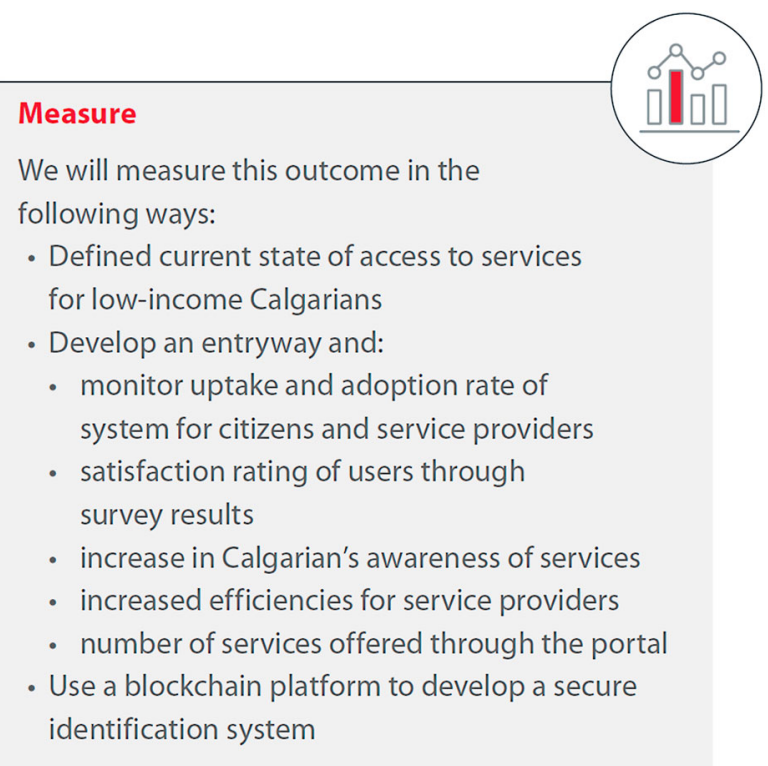

Figure 1. The City of Calgary's Smart City Challenge application sets evaluation criteria for each of its objectives, each being steeped in quantification and realist epistemological frameworks. 


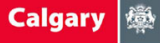

Smart City Elements

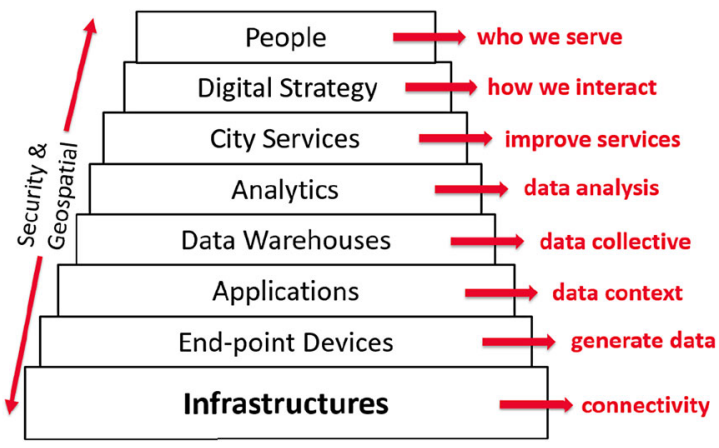

Figure 2. A slide from an event the City of Calgary organized to claim that 'Calgary is already a smart city'.

These epistemological frameworks and priorities serve to frame urban problems as technical in nature and requiring expert knowledges to address. The city here serves quite simply as a foundation for other actors to exert neo-colonial power on the city; Open Calgary exists to expand the network of civil society institutions involved in governance and profit generation in the smart city, such as, primarily, private sector tech businesses as well as those who stand to benefit from their involvement. If data infrastructures can effectively frame a perceived problem as technical in nature, then technical solutions logically will seem to solve them, and these technical solutions are by and large seen to exist in market-driven environments such as the private sector. Urban problems, for the Calgary smart city, emerge from a lack of the right kind or the right amount of data - specifically, numeric and Euclidean data signifying quantities and locations. The discursive power of the Calgary smart city would derive to a large degree from being able to communicate such quantities and locations; that is to say, success stories, best practices, policy mobility and (inter)national recognition are here tied to particular forms of urban knowledge being generated, circulated, analysed and acted upon. This sort of technical framing has been widely theorized in other contexts (Ferguson, 1990; Li, 2007), and yet holds great explanatory value for understanding smart cities. Speaking of organizational political-economies rather than urban geographies, Arena (2012, p. xxviii) gives us a contrasting principle that the smart city could focus on but that is less amenable to technical solutions: ' $[\mathrm{N}]$ onprofits are generally encouraged to approach social problems as technical in nature, requiring the application of expert knowledge, rather than to frame issues as deeply rooted, class-based conflicts.' In other words, such technical framings obfuscate a range of other approaches toward citybuilding and toward knowing the city.

Despite the above focus on activities within the municipal government, the City of Calgary serves as an intermediary between digital technologies, urban space, and private business interests. More specifically, Calgary's smart city is, like many others in extant research, a way of opening new markets for private businesses such as the open data company Socrata (and its parent company Tyler Technologies ${ }^{3}$ ), Facebook and the telecommunications company Telus. Facebook in particular is the largest consumer of Calgary's YYC Internet Exchange, ${ }^{4}$ a shared digital infrastructure that as of our writing connects 64 institutions across the city; many of the other participants are likewise for-profit businesses. Telus and the Internet Service Provider (ISP) Xplornet are prominent users of the YYC Internet Exchange, exemplifying the strong role our interviewees saw for private telecommunications companies in the Calgary Smart City. Other prominent smart city actors such as the not-for-profit group Cybera - a self-proclaimed 'digital accelerator' - leverage private sector discursive framings and logics of the private sector to 'driv[e] Alberta's economic growth through the use of digital technology. ${ }^{5}$ In this way, the Calgary smart city is deeply infused with both direct private sector interests and a plethora of governmental and non-profit institutional support structures. This is key to understanding the particularly neo-colonial relations that Calgary's smart city proffers.

\section{Legibility}

Calgary's smart-city agenda forms a complex socio-technical assemblage (Kitchin \& Lauriault, 2018) where sensors, infrastructure and platforms are embedded within larger institutional and corporate landscapes - and therefore enmeshed with an array of ideologies, industrial practices and economic rationalities. As such, the Calgary smart city is, much like other initiatives of this sort, contingent, processual and relational (Karvonen et al., 2018). For our purposes, amongst this complex assemblage, we focus primarily on Open Calgary. We argue that conceptualizing Open Calgary as a system of legibility draws to our attention the ways in which open data functions as a normalizing and legitimizing apparatus of a class with technological know-how and a veneer of digital neutrality. This rethinking of open data further allows us to see how it serves as a key mechanism for digital neo-colonialism, in that relations of dominance and extraction are justified through elements of platforms such as database structures, data models, relational schema, and acceptable nomenclature. Open databases largely derive their rudimentary technical frameworks from the private companies that deliver open data systems - Socrata, Azavea and Esri are three key actors. Phenomena in the world come to be known if they adhere to these technical frameworks, and only come to be known in terms of the qualities and attributes the framework allows. In this argument we draw on Scott's (1998) notion of legibility; we are further inspired by Spivak's (1988) critique that discursive structures (dis)allow particular forms of expression, knowledge and social ontologies.

Open Calgary contains a range of technical and institutional limitations on the knowledges that it circulates as data. Open data staff must place datasets into one of 
eleven categories, which include business and economic activity, demographics, environment and government. Open data staff must tag all data with an arbitrary set of labels that are meant to make the datasets more findable. They must be standard, machine-readable formats such as comma-separated values (CSV), Excel tables (xlsx) or JavaScript Object Notation (JSON).

Our interviewee Alan informed us that the Socrata software - on which Open Calgary is built - provides most of these base technical affordances as part of its software. As with the other cities using Socrata, the categorization schemes, dataset preview styles and default data types all are embedded within the software, which in turn is modifiable by city staff. Alan said that the way in which Calgary adapts the delivered software is not a science' and largely retains the default settings. In this way, Socrata holds strong sway over the categories, attributes, observations and qualities that cities generate to know, govern and administer urban spaces. The municipal government, while still an important actor in this data ecosystem, implements the epistemological framework that Socrata has created and that prioritizes the framings we elucidated above. As Bowker and Star (2000) helpfully remind us, such categorizations, standards and (digital) infrastructures materialize an epistemological politics - a claim about how a phenomenon such as a city and its denizens should be known. They make some activities, knowledges, relations, and phenomena more legible than others, by providing a platform for their recording and dissemination (Burns, 2014).

\section{Repercussions}

Calgary's neo-colonial smart city relations raise important questions about digital technologies' mechanisms of inclusion and exclusion. It is tempting to locate the politics of inclusion on an axis of visibility, wherein legitimacy derives from legibility within a smart digital infrastructure. If neo-colonial smart city systems prioritize realist and Euclidean epistemologies made legible in socio-technical assemblages such as databases, then one might infer that empowerment lies in incorporating non-realist and nonEuclidean into these assemblages. That is, making 'alternative' epistemologies visible in open data platforms might antagonize neo-colonialism.

We want to contest this position by drawing attention to the terms on which phenomena come to be visible in the smart city. Namely, in the digital neo-colonial milieu, the terms of visibility remain largely within the purview of diffuse systems of control that, while contestable and contingent, are difficult to fundamentally re-envision. Opensource open data platforms such as CKAN supply predetermined categorization schemes; non-Euclidean spatial data must on some level conform to technical standards such as transmission protocols; 'alternative' epistemologies must still situate within particular discursive regimes (Fraser, 1988). In other words, the conditions of possibility for visibility itself are suffuse with uneven relations of digital power (Burns \& Andrucki, 2020). We juxtapose this point with the recognition that visibility itself can be a mechanism of control and indeed physical danger (Young \& Gilmore, 2014). The right to stay illegible to systems of digital governance remains one of many potential responses to deepening neo-colonial relations. More important than seeking visibility and legibility, then, is the practice of directly contesting the epistemological claims and priorities of the smart city. One way to approach this tactic is to follow the possibilities highlighted by our interviewee Jean, who told us that 'Municipalities are reclaiming that term ['smart city'], by the way. They're taking it back from industry - we're starting to learn that platforms will not just solve all our problems.' In other words, the very term 'smart city' itself, while articulated to support private-sector business interests via a technicist epistemology, is contestable and amenable to rearticulation by city governments; presumably, organized resistance might provide useful rearticulations, as well.

\section{RESISTING DIGITAL NEO-COLONIALISM}

Framing these processes and relations as neo-colonial rather than simply colonial, as we do, necessitates rethinking common tactics and strategies for resisting them. In other words, we contend that resisting digital neo-colonialism entails articulating and enacting a politics of resistance that differs from those we might espouse to resist its colonial counterpart. We see these tactics and strategies as complementary and as mutually necessary, rather than as counter-productive or antagonistic; the main point is that they are different. Here, we grapple with tactics related only to digital neo-colonialism, and underscore the ways in which some approaches reinscribe the discursive framing of neoliberal, atomized, and rational decisionmaking subjects that digital neo-colonialism presupposes and indeed benefits from producing.

A range of resistance tactics have been proposed across the literature that mobilize an individuated, rational, independent (in the Cartesian sense), and technologically savvy subject. This digital Cartesian subject extends the legitimacy of neo-colonialism's Euclidean, realist epistemologies, in that they animate similar philosophical assumptions and intellectual lineages. As Brown (2015) has shown, neoliberalism also assumes this subjectivity and negates collective organizing and structural conditions. Cheney-Lippold (2018), for instance, advocates installing a web browser plug-in called TrackMeNot ${ }^{6}$ that submits random search phrases to various search engines every six seconds. This data flooding intends to confuse the hundreds of algorithms that track individual internet users to assign them to a user category - borrowing from Weber, Cheney-Lippold calls these categories 'measurable types'. TrackMeNot complicates Google algorithms' task of assigning users to the measurable type of, say, a gay male between the ages of 18 and 24 years living in a major North American city who likes electronic music and shopping at Banana Republic. These algorithms are increasingly a key component of the smart city (see Sidewalk Labs), and TrackMeNot can thus be construed as an effective resistance strategy to 
digital neo-colonialism. Separately, academic researchers and civil activists alike are developing wearable masks and facial tattoo designs that confuse facial recognition algorithms (McMullan, 2018; Zavyalova, 2017). These strategies emerge in the context of increasingly pervasive militarized surveillance and invasive commercial applications of facial recognition and facial analysis algorithms in the smart city (Fussell, 2019; Mozur, 2019). In another example of such tactics, some drivers have displayed database manipulation code in place of their licence plates on their vehicles. Presumably, the code will 'trick' traffic enforcement cameras - on, for example, toll roads or those monitoring vehicles' speeds - by instructing the traffic management software to delete entire databases of traffic 'violators'. In more technical language, the licence plate displays SQL code that, when converted to text using OCR software, will inject a 'drop database' command into the database management software. ${ }^{7}$

These strategies and tactics, while useful in many regards, rely on an atomized individual to 'choose' to perform a political resistance against the smart city. These singular acts of resistance presume the liberal subject who voluntarily opts-in to political contestation. We argue that in this way, such political strategies leave unquestioned - and thus reinscribe the legitimacy of the mode of subject-production that exemplifies the neocolonial smart city.

Whereas resisting digital colonial relations might perhaps direct efforts toward the state and its proxies (e.g., police or supranational institutions), resisting digital neocolonialism requires contesting the diffuse sets of political-economic relations, capital accumulation practices, and data extraction and selling exchanges that are symptomatic of smart cities. Currently, scholars have conceived of these relations, practices and exchanges as digital colonialism, but doing so has implications for (misdirected) political and organizing energies. More directly, as we explained above, these relations, practices and exchanges are dominated by private businesses and those who stand to benefit from their interventions. What does it mean in practice? By way of example, it is not enough for countries of the Global South to require companies to store their data in local servers (in an attempt to protect their citizens from the prying eyes of imperial powers). It is also insufficient to rely on virtual private networks (VPNs), if the intention is to direct resistance toward surveillant states. Rather, we must collectively fight for legislation that prevents big tech companies from exploiting these data. More generally, we align with Kwet (2019) in calling for resistance to invest the ideological field, and to counter what he calls the 'tech hegemony' discourse.

We might instead contrast these approaches with strategies that mobilize collective organizing toward structural anti-capitalist shifts. In this, we have in mind strategies such as those Noble (2018) suggests, toward legislatively dissolving the major actors that enact digital neo-colonial technologies and practices. Noble argues that major search engine companies - many of which, like Alphabet, are invested in smart cities - subvert democratic values by agglomerating control over racialized and gendered discourses, and the national policies that protect them. These companies obfuscate the algorithmic methods by which they return particular pieces of information to their users, and by extension, how they represent urban phenomena (see also Pasquale, 2015). While she does not explicitly say so, one might infer that for Noble, individual acts of resistance are less effective political strategies than demanding changes to the structural conditions that enable digital neo-colonialism. A related strategy might be to develop and cultivate communities that, through the organization and mobilization of consciousness around political-economic oppression, might enable and indeed normalize widespread non-compliance to digital neocolonialism. While there are many potential manifestations of this goal, the Tor Project ${ }^{8}$ demonstrates some of these political tactics. The Tor Project is a network that anonymizes internet traffic, allowing its users to avoid web surveillance and tracking. It relies on multiple installations of its software, and to work particularly effectively, requires a large network of people who have installed Tor on their computers. The Tor Project does indeed require individuals to 'opt-in' by downloading and installing its software, its ultimate goal is to organize a large community of users to make anonymous internet browsing more efficient, normalized and widespread. In these ways, it combines elements of individual action with collective organizing. What is needed, then, is a sort of Tor community for anonymizing life in the smart city. We see each of these strategies as inherently anticapitalist, in that it is the datafication and valorization of everyday life, alienated from the individual whose labour/activities produced them, that is the fundamental base on which digital neo-colonialism relies, and parallels the capitalist process. Making this process more difficult, or in some cases impossible, is an anti-capitalist practice. More broadly, creating communities of resistance can undermine the power of digital neo-colonialism in smart cities.

\section{CONCLUSIONS}

With this article, our intent has been to foreground the epistemological implications of smart urbanism: How is data collection and processing affecting what can be known of and experienced in regional and urban spaces or environments? In reflecting on this question, we acknowledge that digitally mediated relations between individuals, public authorities and private actors are imper$\mathrm{ial}$ in nature, in that they involve forms of political, cultural and economic domination. The variegated forms of such domination, however, remain under-theorized. We have felt the need for further elaboration and clarification of digital imperialism, and this article suggests that the notion of digital neo-colonialism is a valuable category of analysis for our understanding of smart urbanism.

We contend that the growing literature on digital colonialism can be advanced by operating a distinction between colonialism and neo-colonialism. By extending the metaphor 
with historically and geographically situated colonial experiences, we differentiate two concurrent processes of domination. On the one hand, digital colonialism can shed light to the state-driven forms of direct control exerted over digitally entrenched individuals. On the other hand, neo-colonialism appears as a useful concept to document and analyse more diffuse forms of domination that operate through the imposition of new normative frameworks and involve a complex web of public and private actors.

To establish the heuristic value of the proposed conceptual apparatus, we applied it to the case study of Calgary. Overall, the City of Calgary's epistemological framing of the smart city aligns with a realist understanding of knowledge production, where urban life is translated into quantifiable, mappable, and standardizable data. We argue that such epistemological priorities contribute to a diffusion of norms and measures that marginalize nonEuclidian and non-Cartesian ways of understanding the city. In other words, Calgary's smart city initiatives exert an indirect form of control over data production - which we call forms of digital neo-colonialism. The concept, in turns, allows us to highlight how Calgary's smart city framework obfuscates particular forms of expression, knowledge, and social ontologies. It raises the question of legibility for urban practices that do not fit this framework, and subsequently the capacity for marginalized urbanites to leverage resources in the digital era.

Finally, this article seeks to establish a dialogue with activist circles and discusses the implications of digital neo-colonialism for strategies of resistance against the datafication and commodification of everyday urban experience. In doing so, it argues for more attention to be placed on broader forms of structural change, as opposed to more individualized means of resistance.

\section{DISCLOSURE STATEMENT}

No potential conflict of interest was reported by the authors.

\section{FUNDING}

This work was supported by the Andrew W. Mellon Foundation [subgrant 'Open Data for a Smarter City']; the Calgary Institute for the Humanities, University of Calgary ['Social Justice and the Smart City']; the Cumming School of Medicine, University of Calgary [grant number 1]; the Faculty of Arts, University of Calgary [grant number 1043685]; the O'Brien Institute for Public Health, University of Calgary [grant number 1]; and Social Sciences and Humanities Research Council of Canada [grant number 430-2018-00627].

\section{NOTES}

1. FaceApp allowed users to take pictures of people and apply various filters to modify the person's face. It was commonly used to make someone appear 'old' or as a different gender.

2. It is meaningful that the reference to Habermas's work occurs rarely in these literatures: while it may serve as intellectual heritage, it does not yet provide a rich conceptualization of colonialism from which scholars of digital colonialism currently draw (at least not explicitly). Indeed, in Radical Technologies, Greenfield (2017, p. 32, added emphasis) mixes references with Lefebvre's (2014) work on everyday life: 'I prefer to see it for what it is: the colonization of everyday life by information technologies.'

3. See https://www.tylertech.com/products/socrata.

4. See https://yycix.ca.

5. This quotation is from the Cybera home page, https:// www.cybera.ca.

6. See https://trackmenot.io/.

7. See https://hackaday.com/2014/04/04/sq1-injectionfools-speed-traps-and-clears-your-record/ and https:// www.wired.com/story/null-license-plate-landed-one-hac ker-ticket-hell/.

8. See www.torproject.org/.

\section{ORCID}

Morgan Mouton (D) http://orcid.org/0000-0002-3324-
4808
Ryan Burns (DD http://orcid.org/0000-0001-5025-4947

\section{REFERENCES}

Arena, J. (2012). Driven from New Orleans: How nonprofits betray public housing and promote privatization. University of Minnesota Press.

Bhaskar, R. (2008). A realist theory of science. Routledge.

Bowker, G. C., \& Star, S. L. (2000). Sorting things out: Classification and its consequences. The MIT Press.

Brown, W. (2015). Undoing the demos: Neoliberalism's stealth revolution. MIT Press.

Burawoy, M. (1998). The extended case method. Sociological Theory, 16(1), 4-33. https://doi.org/10.1111/0735-2751.00040

Burns, R. (2014). Moments of closure in the knowledge politics of digital humanitarianism. Geoforum, 53, 51-62. https://doi.org/ 10.1016/j.geoforum.2014.02.002

Burns, R., \& Andrucki, M. (2020). Smart cities: Who cares? Environment and Planning A: Economy and Space, 1-19. https://doi.org/10.1177/0308518X20941516

Burns, R., \& Wark, G. (2019). Where's the database in digital ethnography? Exploring database ethnography for open data research. Qualitative Research, 20(5), 598-616. https://doi.org/ 10.1177/1468794119885040

Calzada, I. (2017). The techno-politics of data and smart devolution in city-regions: Comparing Glasgow, Bristol, Barcelona, and Bilbao. Systems, 5(1), 1-18. https://doi.org/10.3390/systems 5010018

Cheney-Lippold, J. (2018). We are data: Algorithms and the making of our digital selves. NYU Press.

Couldry, N., \& Mejias, U. A. (2019a). Data colonialism: Rethinking big data's relation to the contemporary subject. Television \& New Media, 20(4), 336-349. https://doi.org/10.1177/1527476418 796632

Couldry, N., \& Mejias, U. A. (2019b). The costs of connection: How data is colonizing human life and appropriating it for capitalism. Stanford University Press. 
Datta, A. (2018). The digital turn in postcolonial urbanism: Smart citizenship in the making of India's 100 smart cities. Transactions of the Institute of British Geographers, 43(3), 405419. https://doi.org/10.1111/tran.12225

Davis, M. (1998). Ecology of fear: Los Angeles and the imagination of disaster. Metropolitan Books.

Deleuze, G. (1990). Post-Scriptum sur les sociétés de contrôle. Pourparlers (1972-1990). de Minuit.

Dittmer, J. (2010). Textual and discourse analysis. In D. DeLyser, S. Herbert, S. Aitken, M. Crang, \& L. McDowell (Eds.), The Sage handbook of qualitative geography (pp. 274-286). Sage.

Ferguson, J. (1990). The anti-politics machine: 'Development', depoliticization and bureaucratic power in Lesotho. Cambridge University Press.

Flint, C., \& Taylor, P. J. (2018). Political geography: World-economy, nation-state, and locality. Routledge.

Foucault, M. (2004). Naissance de la biopolitique. Cours au collège de France (1978-1979). Seuil.

Fraser, N. (1988). Talking about needs. Public Culture, 1(1), 39-51. https://doi.org/10.1215/08992363-1-1-39

Fussell, S. (2019). Now your groceries see you, too. The Atlantic. https://www.theatlantic.com/technology/archive/2019/01/ walgreens-tests-new-smart-coolers/581248/.

Greenfield, A. (2017). Radical technologies. Verso.

Habermas, J. (1989). The theory of communicative action. Polity.

Harvey, D. (2014). The new imperialism: Accumulation by dispossession. The Socialist Register, 40, 63-87. https://socialistregister. com/index.php/srv/article/view/5811/2707

Hollands, R. G. (2008). Will the real smart city please stand up?: Intelligent, progressive or entrepreneurial? City, 12(3), 303320. https://doi.org/10.1080/13604810802479126

Hollands, R. G. (2015). Critical interventions into the corporate smart city. Cambridge Journal of Regions, Economy and Society, 8(1), 61-77. https://doi.org/10.1093/cjres/rsu011

ICANN. (n.d.). Welcome to the global community! Retrieved October 9, 2019, from https://www.icann.org/get-started

Johnson, P. A., Acedo, A., \& Robinson, P. J. (2020). Canadian smart cities: Are we wiring new citizen-local government interactions? The Canadian Geographer/Le Géographe canadien, 64(3), 402-415. https://doi.org/10.1111/cag.12623

Jørgensen, M., \& Phillips, L. (2002). Discourse analysis as theory and method. Sage.

Karvonen, A., Cugurullo, F., \& Caprotti, F. (2018). Inside smart cities: Place, politics and urban innovation. Routledge.

Kitchin, R. (2014a). The data revolution: Big data, open data, data infrastructures and their consequences. Sage.

Kitchin, R. (2014b). The real-time city? Big data and smart urbanism. GeoJournal, 79(1), 1-14. https://doi.org/10.1007/s10708013-9516-8

Kitchin, R., \& Lauriault, T. (2018). Towards critical data studies: Charting and unpacking data assemblages and their work. In J. Thatcher, J. Eckert, \& A. Shears (Eds.), Thinking big data in geography (pp. 3-20). University of Nebraska Press.

Kitchin, R., Lauriault, T., \& McArdle, G. (2015a). Knowing and governing cities through urban indicators, city benchmarking and real-time dashboards. Regional Studies, Regional Science, 2 (1), 6-28. https://doi.org/10.1080/21681376.2014.983149

Kitchin, R., Lauriault, T., \& McArdle, G. (2015b). Smart cities and the politics of urban data. In S. Marvin, A. Luque-Ayala, \& C. McFarlane (Eds.), Smart urbanism: Utopian vision or false Dawn? (pp. 16-33). Routledge.

KPMG. (2017). Overview of China's cybersecurity law. https:// assets.kpmg/content/dam/kpmg/cn/pdf/en/2017/02/overviewof-cybersecurity-law.pdf.

Krivý, M. (2018). Towards a critique of cybernetic urbanism: The smart city and the society of control. Planning Theory, 17(1), 8-30. https://doi.org/10.1177/1473095216645631
Kwet, M. (2019). Digital colonialism: US Empire and the new imperialism in the global south. Race E Class, 60(4), 3-26. https://doi.org/10.1177/0306396818823172

Lefebvre, H. (2014). Critique of everyday life. Verso.

Lenin, V. (1999). Imperialism: The highest stage of capitalism. Resistance.

Levenda, A. M., Keough, N., Rock, M., \& Miller, B. (2020). Rethinking public participation in the smart city. The Canadian Geographer/Le Géographe canadien, 64(3), 344-358. https://doi.org/10.1111/cag.12601.

Li, T. M. (2007). The will to improve. Duke University Press.

Liang, F., Das, V., Kostyuk, N., \& Hussain, M. (2018). Constructing a data-driven society: China's social credit system as a state surveillance infrastructure. Policy E Internet, 10(4), 415-453. https://doi.org/10.1002/poi3.183

MacKay, F. (2004). Indigenous people's rights to lands, territories and resources: Selected international and domestic legal considerations. In P. Groppo (Ed.), Land reform: Land settlement and cooperatives (n.p.). Food and Agriculture Organization of the United Nations (FAO).

Mann, M., \& Daly, A. (2019). (Big) data and the north-in-south: Australia's informational imperialism and digital colonialism. Television E New Media, 20(4), 379-395. https://doi.org/10. 1177/1527476418806091

Marvin, S., Luque-Ayala, A., \& McFarlane, C. (2015). Smart urbanism: Utopian vision or false dawn? Routledge.

McMullan, T. (2018). Fighting AI surveillance with scarves and face paint. Medium. https://medium.com/s/story/fighting-aisurveillance-with-scarves-and-face-paint-6b634ef174a 1

Mozur, P. (2019). In Hong Kong protests, faces become weapons. The New York Times. https://www.nytimes.com/2019/07/26/ technology/hong-kong-protests-facial-recognition-surveillance. html

Murakami-Wood, D., \& Mackinnon, D. (2019). Partial platforms and oligoptic surveillance in the smart city. Surveillance $\mathcal{E}^{\circ}$ Society, 17(1/2), 176-182. https://doi.org/10.24908/ss.v17i1/2. 13116

Neff, G., \& Nafus, D. (2016). Self-tracking. MIT Press.

Nkrumah, K. (1966). Neo-colonialism: The last stage of imperialism. International Publ.

Noble, S. (2018). Algorithms of oppression: How search engines reinforce racism. New York University Press.

Odendaal, N. (2016). Smart city: Neoliberal discourse or urban development tool? In J. Grugel \& D. Hammett (Eds.), The Palgrave handbook of international development (pp. 615-633). Palgrave Macmillan.

Oppermann, D. (2018). From Bandung to the DNS. In internet governance in the global south. In D. Oppermann (Ed.), History, theory, and contemporary debates (pp. 12-41). Núcleo de Pesquisa em Relações Internacionais (NUPRI).

Pasquale, F. (2015). The black box society: The secret algorithms that control money and information. Harvard University Press.

Picon, A. (2013). Smart cities: Théorie et critique d'un idéal autoréalisateur. $\mathrm{B} 2$.

Picon, A. (2015). Smart cities: A spatialised intelligence. Wiley.

Picon, A. (2018). Urban infrastructure, imagination and politics: From the networked metropolis to the smart city. International Journal of Urban and Regional Research, 42(2), 263-275. https://doi.org/10.1111/1468-2427.12527

Richardson, L. (2018). Feminist geographies of digital work. Progress in Human Geography, 42(2), 244-263. https://doi.org/10.1177/ 0309132516677177

Ruckenstein, M., \& Schüll, N. D. (2017). The datafication of health. Annual Review of Anthropology, 46(1), 261-278. https://doi.org/ 10.1146/annurev-anthro-102116-041244

Sadowski, J. (2019). When data is capital: Datafication, accumulation, and extraction. Big Data Eं Society, 6(1). https://doi. org/10.1177/2053951718820549 
Sadowski, J., \& Bendor, R. (2019). Selling smartness: Corporate narratives and the smart city as a sociotechnical imaginary. Science, Technology, EO Human Values, 44(3), 540-563. https:// doi.org/10.1177/0162243918806061

Sadowski, J., \& Pasquale, F. A. (2015). The spectrum of control: A social theory of the smart city. First Monday, 20(7). https://doi. org/10.5210/fm.v20i7.5903

Sartre, J.-P. (2005). Colonialism and neocolonialism. Routledge.

Scott, J. C. (1998). Seeing like a state: How certain schemes to improve the human condition have failed. Yale University Press.

Söderström, O., Paasche, T., \& Klauser, F. (2014). Smart cities as corporate storytelling. City, 18(3), 307-320. https://doi.org/10. 1080/13604813.2014.906716

Spivak, G. (1988). Can the subaltern speak? In R. Morris (Ed.), Can the subaltern speak? Reflections on the history of an idea (pp. 2178). Columbia University Press.

Stingl, A. (2015). The digital coloniality of power: Epistemic disobedience in the social sciences and the legitimacy of the digital age. Lexington Books.

Thatcher, J., O'Sullivan, D., \& Mahmoudi, D. (2016). Data colonialism through accumulation by dispossession: New metaphors for daily data. Environment and Planning D: Society and Space, 34(6), 990-1006. https://doi.org/10.1177/0263775816633195
Townsend, A. M. (2013). Smart cities: Big data, civic hackers, and the quest for a new utopia. WW Norton \& Company.

Vanolo, A. (2014). Smartmentality: The smart city as disciplinary strategy. Urban Studies, 51(5), 883-898. https://doi.org/10. 1177/0042098013494427

Wallerstein, I. (2004). World-systems analysis: An introduction. Duke University Press.

White, P. (2018). ICANN, new gTLDs and the global south. In internet governance in the global south. In D. Oppermann (Ed.), History, theory, and contemporary debates (pp. 207-249). International Relations Research Center Núcleo de Pesquisa em Relações Internacionais (NUPRI).

Young, J. C. (2019). The new knowledge politics of digital colonialism. Environment and Planning A: Economy and Space, 51(7), 14241441. https://doi.org/10.1177/0308518X19858998

Young, J. C., \& Gilmore, M. (2014). Subaltern empowerment in the geoweb: Tensions between publicity and privacy. Antipode, 46 (2), 574-591. https://doi.org/10.1111/anti.12056

Young, R. J. (2016). Postcolonialism: An historical introduction. Blackwell.

Zavyalova, V. (2017). Hiding from artificial intelligence in the age of total surveillance. Russia Beyond. https://www.rbth.com/ science_and_tech/2017/07/22/hiding-from-artificialintelligence-in-the-age-of-total-surveillance_808692 